\title{
Soluble amyloid- $\beta$, effect on cerebral arteriolar regulation and vascular cells
}

\author{
Hans H Dietrich*1, Chuanxi Xiang², Byung H Han², Gregory J Zipfel³ and David M Holtzman
}

\begin{abstract}
Background: Evidence indicates that soluble forms of amyloid- $\beta$ (A $\beta$ ) are vasoactive, which may contribute to cerebrovascular dysfunction noted in patients with Alzheimer's Disease and cerebral amyloid angiopathy. The effects of soluble $A \beta$ on penetrating cerebral arterioles - the vessels most responsible for controlling cerebrovascular resistance - have not been studied.

Results: Freshly dissolved $A \beta_{1-40}$ and $A \beta_{1-42}$, but not the reverse peptide $A \beta_{40-1}$ constricted isolated rat penetrating arterioles and diminished dilation to adenosine tri-phosphate (ATP). $A \beta_{1-42}$ also enhanced ATP-induced vessel constriction. $A \beta_{1-40}$ diminished arteriolar myogenic response, and an anti-A $\beta$ antibody reduced $A \beta_{1-40}$ induced arteriolar constriction. Prolonged $A \beta$ exposure in vessels of $\operatorname{Tg} 2576$ mice resulted in a marked age-dependent effect on ATP-induced vascular responses. Vessels from 6 month old Tg2576 mice had reduced vascular responses whereas these were absent from 12 month old animals. $A \beta_{1-40}$ and $A \beta_{1-42}$ acutely increased production of reactive oxygen species (ROS) in cultured rat cerebro-microvascular cells. The radical scavenger MnTBAP attenuated this A $\beta$-induced oxidative stress and $A \beta_{1-40}$-induced constriction in rat arterioles.
\end{abstract}

Conclusions: Our results suggest that soluble $A \beta_{1-40}$ and $A \beta_{1-42}$ directly affect the vasomotor regulation of isolated rodent penetrating arterioles, and that ROS partially mediate these effects. Once insoluble A $\beta$ deposits are present, arteriolar reactivity is greatly diminished.

\section{Background}

Amyloid beta $(\mathrm{A} \beta)$ peptides are naturally occurring cleavage products of the amyloid precursor protein and produced via $\beta$ - and $\gamma$-secretase resulting in soluble $A \beta$ monomers [1]. Important species include peptides containing 40 and 42 amino acid residues $\left(A \beta_{1-40}\right.$ and $\left.A \beta_{1-42}\right)$ [2]. Monomers of $A \beta$ can aggregate resulting in deposits of fibrillar $A \beta$ both as neuritic plaques and, within blood vessels, as cerebral amyloid angiopathy (CAA). Such deposits are hallmarks of Alzheimer's Disease (AD) [1]. Several lines of evidence suggest that not only $A \beta$ aggregates but soluble $A \beta$ species may also contribute to $A D$ with its vasoactive properties. Cerebral hypoperfusion prior to the onset of AD has been observed [3]. In animal models of $\mathrm{AD}$, some but not all studies suggest that solu-

\footnotetext{
* Correspondence: DietrichH@nsurg.wustl.edu

${ }^{1}$ Department of Neurological Surgery, Hope Center for Neurological Disorders, and Alzheimer's Disease Research Center, Washington University School of Medicine, St Louis, MO, 63110, USA

Full list of author information is available at the end of the article
}

ble $A \beta$ may decrease myogenic response, cerebral blood flow (CBF) and vasodilator responses [4-10]. This implies that soluble $A \beta$ may have an effect on vascular regulation possibly affecting neuronal function [5], potentially contributing to ischemic brain damage [4]. To elucidate the vascular effects of soluble $A \beta$ on the cerebral circulation, studies infusing soluble $A \beta$ into rat [11] or superfusing mouse cortex [12] found that soluble $A \beta$ acutely decreased CBF and response to vasodilators, it also increased vascular resistance and constrictor response. In ex vivo studies, soluble $A \beta$ causes cerebral artery constriction, reduced dilation and/or increased constriction to endothelium-dependent dilators and vasoconstrictors, respectively $[7,12-16]$. The mechanism(s) by which soluble $A \beta$ interferes with vascular function is not fully understood. But increased production of reactive oxygen species (ROS) has been described [15,17-19]. However, other mechanisms such as increased intracellular calcium activity [16] or decreased endothelial nitric oxide availability [20] have been reported. Because endothelium- 
dependent dilation rather than smooth muscle function $[4,15]$ was impaired, studies concluded that soluble $A \beta$ causes endothelial dysfunction resulting in the observed reduced vasomotor function $[4,15,16]$.

To date, studies examining the functional effects of soluble $A \beta$ on the cerebro-vasculature have been limited to cortical CBF measurements following topical application of soluble $A \beta[12]$ and measurements of isolated cerebral arteries exposed to soluble $A \beta[12,20]$. No data regarding intracerebral micro-vessels exist. These vessels are exposed to both soluble $A \beta$ as sites of $A \beta$ clearance [21] and substantial CAA which forms in the vessel wall. Penetrating arterioles contribute significantly to the local regulation of $\mathrm{CBF}$ by controlling as much as $25 \%$ of total arterial resistance, exercising strong myogenic response [22] and differ in physiological response from proximal pial vessels and arteries [23]. For these reasons, it is important to examine the effects of $A \beta$ on these critical microvessels and determine which mechanisms are involved. Finally, the effect of prolonged exposure to endogenous $A \beta$ on cerebral arterioles has not been previously described.

Here we show strong effects of both soluble $A \beta_{1-40}$ and $A \beta_{1-42}$ on both vasoconstriction and vasodilation in penetrating arterioles, these effects are mediated in part by ROS. Further, prolonged exposure to high levels of $A B$ in a mouse model with CAA was accentuated with very poor arteriolar function.

\section{Methods}

\section{Isolation and cannulation of penetrating arterioles}

All procedures were approved by the Washington University Advisory Committee for Animal Resources. Male Sprague-Dawley rats (350-450 g, Harlan, Indianapolis, IN) were anesthetized with pentobarbital sodium $(65 \mathrm{mg} /$ $\mathrm{kg}$ intraperitoneally) and sacrificed. Transgenic $\operatorname{Tg} 2576$ mice (gift of K. Hsaio) and their wild type litter mates on a B6/SJL background were bred in our animal facilities. The mice were anesthetized with Ketamine/Xylazine and sacrificed. The cerebral penetrating arterioles were excised from the distribution of the middle cerebral artery. Arterioles with a length of 500 to $1000 \mu \mathrm{m}$ were transferred to an organ bath ( $2.5 \mathrm{ml}$ volume) mounted on the stage of an inverted video microscope (Zeiss 100TV or Zeiss 200), and cannulated with glass micropipettes. No intraluminal flow was applied and the transmural pressure was set at $50 \mathrm{~mm} \mathrm{Hg}$ (mice) or $60 \mathrm{mmHg}$ (rats) and continuously monitored. We observed the internal diameter of the vessels using a computerized diameter tracking system (Diamtrak, T.O. Neild, Flinders University, Adelaide, Australia) with a spatial resolution of 0.5 $\mu \mathrm{m} /$ pixel and a data acquisition rate of $10 \mathrm{~Hz}$. Rat arterioles averaged a maximum passive diameter of $64.9 \pm 13.6$ $\mu \mathrm{m}$. Mouse arterioles averaged maximum passive diame- ters of $51.8 \pm 7.7 \mu \mathrm{m}$ for WT littermates and $52.7 \pm 7.0$ $\mu \mathrm{m}$ for APPsw mice.

The arterioles were superfused continuously with a physiological saline solution $\left(37.5^{\circ} \mathrm{C} ; \mathrm{pH} 7.3\right)$ of the following composition (in mmol/L): $144 \mathrm{NaCl}, 3 \mathrm{KCl}, 2.5$ $\mathrm{CaCl}_{2}, 1.4 \mathrm{MgSO}_{4}, 2.0$ pyruvate, 5.0 glucose, 0.02 ethylenediaminetetraacetic acid (EDTA), and $2.03-(\mathrm{N}-$ morpholino) propanesulfonic acid (MOPS), $1.21 \mathrm{NaH}_{2} \mathrm{PO}_{4}$. After equilibration, the vessels developed spontaneous tone and we confirmed their viability by changing the extraluminal $\mathrm{pH}$ from 7.3 to 6.8 and from 7.3 to 7.65 . Vessels with poor tone (less than $20 \%$ decrease from the maximum diameter) or poor response to $\mathrm{pH}$ (less than $15 \%$ change in diameter after $\mathrm{pH}$ change) were excluded.

\section{Pharmacological studies}

Stock solutions of commercially available amyloid $\beta$ peptides were prepared in distilled water (one $\mathrm{mmol} / \mathrm{L}$ ), kept frozen until use and diluted in physiological buffer just prior to use. Using Western blot, we confirmed that the preparations contained predominantly monomeric peptides (data not shown). Similarly, adenosine tri-phosphate (ATP) stock was prepared in distilled water $(10 \mathrm{mmol} / \mathrm{L})$ and kept frozen until use. $\mathrm{Mn}$ (III) tetrakis (4-benzoic acid) porphyrin (MnTBAP), catalase and superoxide dismutase (SOD) were used to scavenge oxygen radicals. For dose response or agonist studies, the vessel where pretreated with respective $A \beta$ concentrations for 20 minutes. Agonists such as ATP where applied in the presence of amyloid $\beta$. Purinergic P2X1 receptors were inhibited with pyridoxalphosphate-6-azophenyl-2',4'-disulphonic acid (PPADS, $3 \mu \mathrm{mol} / \mathrm{L}$ ) [24].

Amyloid peptides were purchased from American Peptide Co. (Sunnyvale, CA); all other chemicals were obtained from Sigma (St. Louis, MO).

CAA coverage on TG2576 mouse cerebral arterioles was visualized according to our previously published method using Thioflavin-S (0.005\% in MOPS buffer) to visualize CAA. Qualitatively, the vessels in this study were affected to the same extent by CAA as was shown in our previous publication [8].

\section{Cell Culture}

Rat cerebral microvascular endothelial and smooth muscle cell lines (obtained from Dr. Diglio, Wayne State University, Michigan) $[25,26]$ were cultured in antibiotic free DMEM with $10 \% \mathrm{FCS}$ at $37^{\circ} \mathrm{C}$ at $95 \% \mathrm{CO}_{2}$ and $5 \%$ air. Though cell cultures may have undergone changes compared to native cells, in preliminary experiments we confirmed that the endothelial cells tested positive for endothelial nitric oxide and the smooth muscle cells for $\mathrm{f}$ actin thus retaining their respective main phenotype. Cell suspensions were plated into 96 well plates and grown to near confluency. On the day of experiment, the cells were 
washed with warmed $\left(37^{\circ} \mathrm{C}\right)$ Medium Leibovitz, loaded with the oxygen radical sensitive dye MitoTracker Red $\mathrm{CM}-\mathrm{H}_{2} \mathrm{X}$ Ros (Invtirogen, diluted in Medium Leibovitz at $5 \mu \mathrm{mol} / \mathrm{L}$ ) and incubated for 15 to 20 minutes. After incubation, the cells were washed with warmed Medium Leibovitz, freshly dissolved $\mathrm{A} \beta$ was added (one and two $\mu \mathrm{mol} / \mathrm{L}$ ) immediately before the measurement and the change in fluorescence measured for 30 minutes at $37^{\circ} \mathrm{C}$ with a plate reader (Synergy HTTR with KC4 software, Biotek Instruments, Ex $=475 \pm 15 \mathrm{~nm}, \mathrm{Em}=645 \pm 40$ $\mathrm{nm})$. Oxidation of MitoTracker Red CM- $\mathrm{H}_{2} \mathrm{X}$ Ros by ROS increases the dye's fluorescence 100 -fold rendering it very sensitive as a detector of ROS. In preliminary experiments we also tested $100 \mathrm{nM} \mathrm{A} \beta$ which had insignificant effect and was not used further.

\section{Statistics}

All data are presented as mean \pm SEM, with $n$ representing the number of observations. Statistics were conducted on absolute vessel diameters. Differences were considered significant at $\mathrm{p}<0.05$ and determined by repeated-measures analysis of variance RANOVA with Student-Newman-Keuls test as post test or paired Student's t-test where appropriate. For the $A \beta$ dose response studies, the data are presented as relative diameter change (\% relative vessel Diameter $\left.=\mathrm{D}_{\text {ATP }} / \mathrm{D}_{\text {Tone }}{ }^{* 100}\right)$ where $\mathrm{D}_{\text {Tone }}$ is the baseline diameter of the vessel before the stimulation with ATP, and $D_{\text {ATP }}$ is the diameter of the vessel after the stimulation. For experiments with $A \beta$ preincubation and mouse vessels the data are presented as percent maximal diameter and was calculated by the following formula: \% maximum dilation $=\left[\left(\mathrm{D}_{\text {ATP }}-\mathrm{D}_{\text {tone }}\right) /\right.$ $\left.\left(D_{\max }-D_{\text {tone }}\right)\right]^{*} 100$, where $D_{\max }$ is the maximum diameter of the vessel at $60 \mathrm{~mm} \mathrm{Hg}$ before the development of spontaneous tone [24,27]. This method corrects for changes in arteriolar to due to $A \beta$ incubation. Changes in fluorescence intensity are presented as percent change from time zero time over 30 minutes of observation time.

\section{Results}

Extraluminal application of soluble $A \beta_{1-40}, A \beta_{1-42}$ the reverse peptide $A \beta_{40-1}$ on arteriolar tone and myogenic response

Rat penetrating cerebral arterioles exposed to $A \beta_{1-40}$ had a maximum diameter of $63.2 \pm 4.1 \mathrm{um}$ and developed a spontaneous tone diameter of $46.9 \pm 3.3 \mathrm{um}(\mathrm{n}=8)$. Freshly dissolved $A \beta_{1-40}$ resulted in constriction of penetrating arterioles in a dose dependent manner which was significant at a concentration of 0.1 and $1 \mu \mathrm{mol} / \mathrm{L}$ resulting in a reduction of the tone diameter by $26.3 \pm 2.9 \%$ (Figure 1A).
Vessel exposed to $\mathrm{A} \beta_{1-42}$ had a maximum passive diameter of $78.0 \pm 8.7 \mu \mathrm{m}$ and developed a spontaneous tone diameter of $56.8 \pm 7.1 \mu \mathrm{m}$. Freshly dissolved $A \beta_{1-42}$ constricted the penetrating arterioles significantly at 0.1 and $1 \mu \mathrm{mol} / \mathrm{L}$, an effect similar to that seen with $\mathrm{A} \beta_{1-40}$ (Figure $1 \mathrm{~A})$. However, at one $\mu \mathrm{mol} / \mathrm{L} A \beta_{1-40}$, there was a $13 \%$ stronger constriction compared to $A \beta_{1-42}(p<0.05)$.

Vessels treated with the reverse peptide $A \beta_{40-1}$ had a maximum diameter of $64.8 \pm 7.2 \mu \mathrm{m}$ and a spontaneous tone diameter of $46.6 \pm 5.6 \mu \mathrm{m}(\mathrm{n}=4)$. The reverse peptide had no effect on the tone diameter (Figure 1A).

Myogenic response describes the ability of arterial blood vessels to maintain a constant vessel tone over a range of intraluminal pressures, a mechanism important for cerebral autoregulation. The arterioles used had a maximum diameter of $76.5 \pm 13.5 \mu \mathrm{m}$ and a tone diameter of $60.7 \pm 10.7 \mu \mathrm{m}$ before and of $51.5 \pm 9.3 \mu \mathrm{m}$ after $\mathrm{A} \beta_{1-40}(0.1 \mu \mathrm{mol} / \mathrm{L})$. Under control conditions, vessels maintained their diameter as intraluminal pressure increased from $60 \mathrm{mmHg}$ to $90 \mathrm{mmHg}$ and $120 \mathrm{mmHg}$. After incubation with freshly dissolved $\mathrm{A} \beta_{1-40}(0.1 \mu \mathrm{mol} /$ L) the vessels' ability to maintain myogenic responses was eliminated at $120 \mathrm{mmHg}$ intraluminal pressure but not at $90 \mathrm{mmHg}$. The vessels returned to base line diameters at $60 \mathrm{mmHg}$ indicating that the pressure increase did not permanently damage the vessels (Figure 1B).

\section{Arteriolar response to adenosine tri-phosphate (ATP) and soluble $A \beta_{1-40}$ and $A \beta_{1-42}$}

Extraluminal ATP causes a biphasic vessel response with a transient constriction caused by smooth muscle $\mathrm{P}_{2 \times 1^{-}}$ receptors and a subsequent endothelium dependent dilation via $\mathrm{P}_{2 \mathrm{Y}}$-receptors [24] thus allowing studies of both smooth muscle- and endothelium-dependent responses. We confirmed that ATP causes a transient constriction via $\mathrm{P}_{2 \times 1}$ stimulation in mouse cerebral arterioles. PPADS ( $3 \mu \mathrm{mol} / \mathrm{L}$ ) significantly inhibited constriction to ATP $(100 \mu \mathrm{mol} / \mathrm{L})$ from $-16.6 \pm 1.2 \%$ to $-1.3 \pm 0.7 \%(\mathrm{n}=3)$ while dilation to ATP was unchanged (data not shown). Arterioles treated with $A \beta_{1-40}$ had a passive maximum diameter of $58.6 \pm 3.7 \mu \mathrm{m}$ and spontaneously constricted to $41.2 \pm 3.6 \mu \mathrm{m}(\mathrm{n}=5)$. Vessels treated with $\mathrm{A} \beta_{1-42}$ had a maximum diameter of $69.5 \pm 5.4$ and a tone diameter of $48.2 \pm 4.1 \mu \mathrm{m}$. Both freshly dissolved $\mathrm{A} \beta_{1-40}$ and $\mathrm{A} \beta_{1-42}$ (one $\mu \mathrm{mol} / \mathrm{L}$ ) significantly decreased dilation to ATP indicating that endothelium dependent dilation was reduced (Figure $1 \mathrm{C}$ and $1 \mathrm{D}$ ). While the constrictory response to ATP was unchanged in the presence of $A \beta_{1}$. ${ }_{40}$, we observed an enhanced smooth muscle-dependent constriction with $A \beta_{1-42}$ with $100 \mu \mathrm{mol} / \mathrm{L}$ concentrations of ATP (Figure 1D). Repeated application of ATP alone 

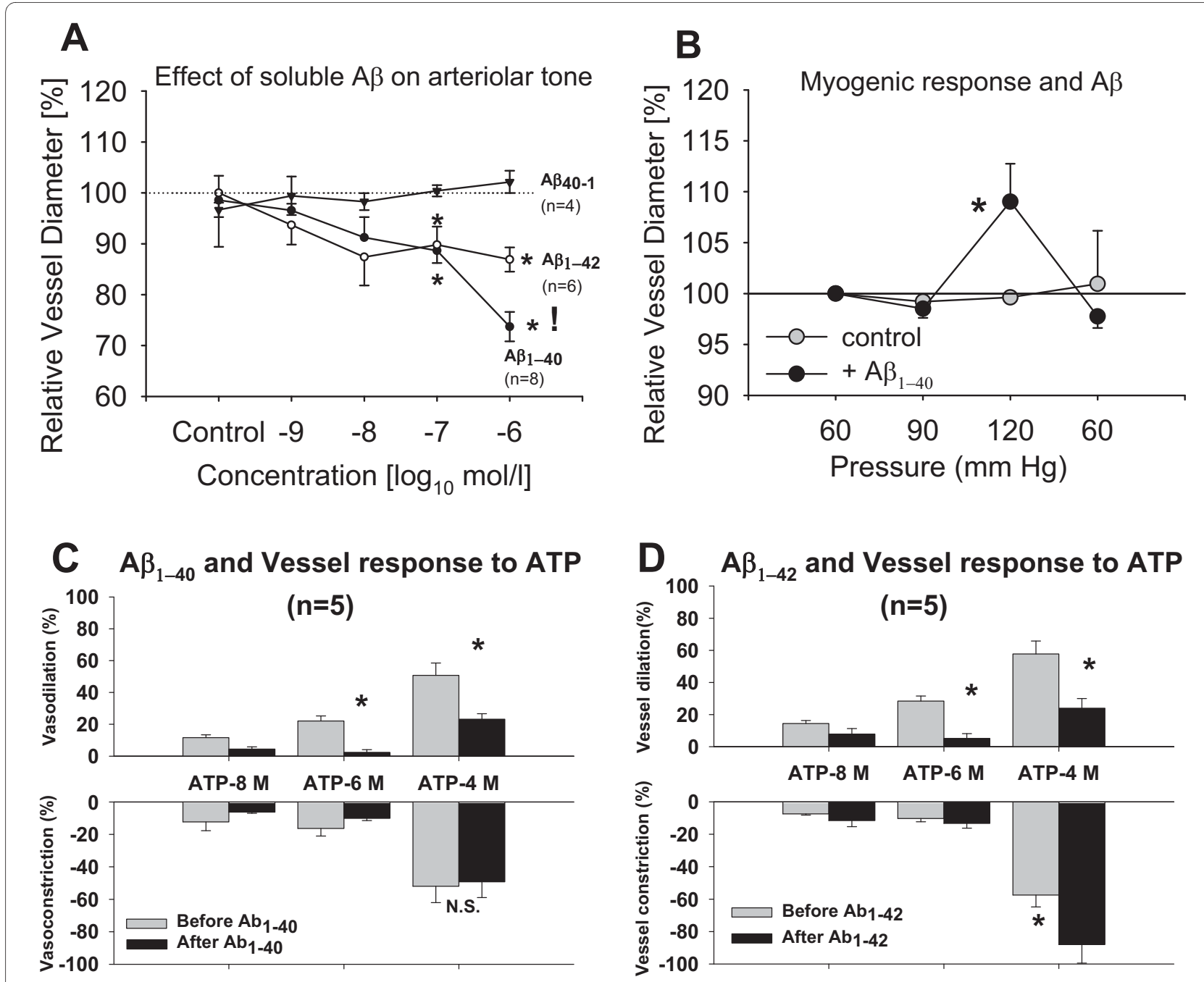

Figure 1 Effect of freshly dissolved $A \beta$ on rat penetrating arteriolar vessel tone, myogenic response and effect on ATP induced vasomotor responses. Cerebral arterioles ex vivo were treated with increasing concentrations of $A \beta_{1-40}, A \beta_{1-42}$ or reverse peptide $A \beta_{40-1}$ and the effect on arteriolar tone measured. (A)A $\beta_{1-42}$ constricts the arterioles similarly to $A \beta_{1-40}$ at $0.1 \mu \mathrm{mol} / \mathrm{L}$ while at $1 \mu \mathrm{mol} / \mathrm{L} A \beta_{1-40}$ has a greater effect. * and ! denote $p<0.05$ from control (ANOVA). The reverse peptide $A \beta_{1-40}$ had no effect. (B) Arterioles pretreated with $A \beta_{1-40}(0.1 \mu \mathrm{mol} / \mathrm{L})$ lose myogenic response at 120 $\mathrm{mmHg}$ intraluminal pressure. Returning to $60 \mathrm{mmHg}$ baseline pressure reestablished control tone diameter. ${ }^{*}$ denotes $p<0.05$ from control $(\mathrm{n}=3$ vessels). Cerebral arterioles were treated with $A \beta$ and vasomotor responses to extraluminal ATP were observed. (C) $A \beta_{1-40}$ and (D) $A \beta_{1-42}$ reduce vasodilation to ATP at 1 and $100 \mu \mathrm{mol} / \mathrm{L}$ concentrations. In addition $A \beta_{1-42}$ also enhances constriction at $100 \mu \mathrm{mol} / \mathrm{L}$ ATP. ${ }^{*}$ denotes $p<0.05$ between before and after amyloid peptide (ANOVA).

$(100 \mu \mathrm{mol} / \mathrm{L})$ did not change the vessel response (relative first constriction of $-66.6 \pm 7.1 \%$ and dilation of $46.2 \pm$ $5.4 \%$ versus repeated constriction of $-53.2 \pm 6.4 \%$ and 39.2 $\pm 7.2 \%$ dilation, $\mathrm{n}=4$ vessel, repeated measures ANOVA).

\section{Soluble $A \beta$ and ROS}

Soluble A $\beta$ may cause ROS production in cerebral vessels. We applied the reactive oxygen scavenger MnTBAP (1 to $100 \mu \mathrm{mol} / \mathrm{L}$ ) and found that in the presence of $\mathrm{A} \beta_{1-40}$ $(1 \mu \mathrm{mol} / \mathrm{L})$ MnTBAP partially restored vessel tone and diameter at the highest MnTBAP concentration (Figure 2). MnTBAP itself had no effect on the vessel diameter.
Microvascular endothelial and smooth muscle cells, $A \beta_{1-40}$ and $A \beta_{1-42}$ and ROS

To study a possible contribution of reactive oxygen species in the observed vessel dysfunction, we loaded cultured rat cerebral microvascular endothelial or smooth muscle cells with the ROS sensitive dye MitoTracker Red $\mathrm{CM}-\mathrm{H}_{2} \mathrm{XRos}$. We found that after 30 minutes of incubation, both freshly dissolved $A \beta_{1-40}$ and $A \beta_{1-42}$ significantly and dose dependently increased ROS production in the two cell types with $A \beta_{1-42}$ having a greater effect in endothelial cells compared $A \beta_{1-40}$ (Figure $3 \mathrm{~A}$ and $3 \mathrm{~B}$ ). In 


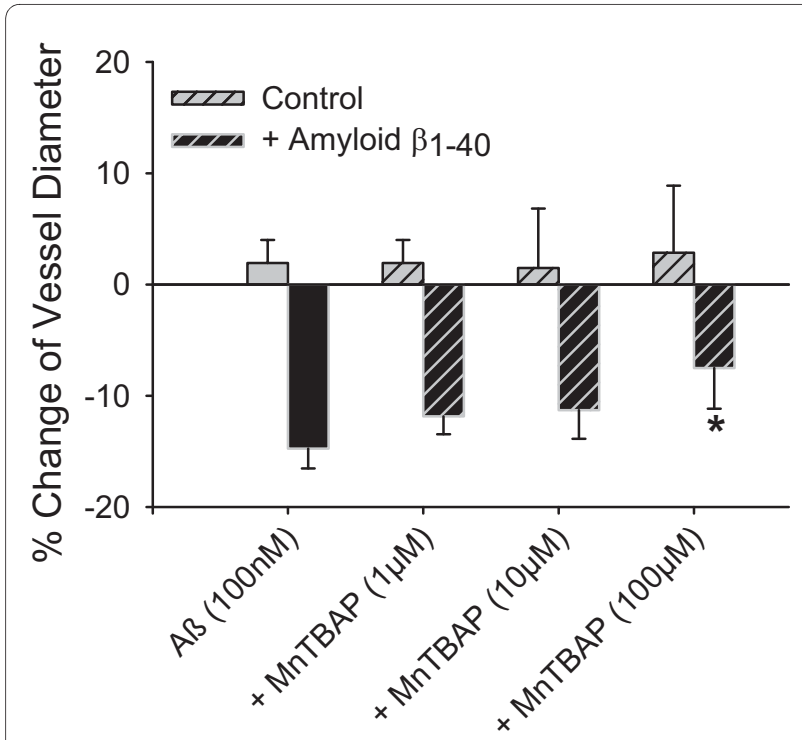

Figure 2 Attenuation of $A \beta_{1-40}$-induced vessel constriction by ROS scavenging. Cerebral arterioles were incubated with $100 \mathrm{nmol} / \mathrm{L}$ $A \beta_{1-40}$ and/or the ROS scavenger MnTBAP. MnTBAP reduced $A \beta_{1-40}$-induced vessel constriction at $100 \mu \mathrm{mol} / \mathrm{L}$ indicating that the $A \beta$ effect is partially due to reactive oxygen species. ${ }^{*}$ denotes $p<0.05$ from $A \beta$ alone $(n=3)$. MnTBAP itself had no effect on the vessel diameter $(n=$ 5).

smooth muscle cells, $A \beta_{1-42}$ was more effective at $1 \mu \mathrm{mol} /$ $\mathrm{L}$ than $\mathrm{A} \beta_{1-40}$ in producing ROS (Figure $3 \mathrm{C}$ and $3 \mathrm{D}$ ). $\mathrm{A} \beta$ $(100 \mathrm{nM})$ induced production of ROS was inhibited by the ROS scavenger MnTBAP (Figure 4), but not by SOD $(60 \mathrm{U} / \mathrm{ml}$, Figure 5) or Catalase $(40 \mathrm{U} / \mathrm{ml}$, data not shown). These data correspond with our ex vivo observation that MnTBAP reduces the effect of $A \beta$ indicating that ROS are involved in the observed vascular dysfunction. However, it is possible that cultured cells may not correctly reflect in vivo situations.

\section{Arteriolar vasomotor responses and chronic exposure to soluble $A \beta$}

We compared vasomotor responses to ATP ex vivo in penetrating arterioles from Tg2576 mice of 3, 6 and 12 months of age compared to age matched wild type littermates. Tg2576 mice develop A $\beta$ deposition in the brain and arterioles beginning at 9 months of age $[28,29]$. Wild type vessels had maximum diameter of $53.5 \pm 6.5 \mu \mathrm{m}$, $61.8 \pm 3.6 \mu \mathrm{m}$ and $54.8 \pm 5.3 \mu \mathrm{m}$ at 3,6 and 12 months of age, respectively. The tone development was $16.5 \pm 6.5 \pm$ $1.2 \%(\mathrm{n}=24), 13.3 \pm 2.9 \%(\mathrm{n}=4)$ and $9.8 \pm 6.2 \%(\mathrm{n}=4)$. Vessels from $\operatorname{Tg} 2576$ mice had a maximum diameter of $54.0 \pm 3.5 \mu \mathrm{m}, 55.8 \pm 2.8 \mu \mathrm{m}$ and $54.6 \pm 2.6 \mu \mathrm{m}$ at 3,6 and 12 months of age, respectively. The tone development was $6.8 \pm 0.5 \%(n=3), 26.5 \pm 8.0 \%(n=4)$ and $1.8 \pm 1.4 \%$ $(\mathrm{n}=6)$. We found no difference in the responses to ATP 3 at months (Figure 6A). At six months of age dilatory response to ATP was reduced in the $\operatorname{Tg} 2576$ vessels compared to wild type vessels. At 12 months of age, both dilatory and constrictory vasomotor responses to ATP were virtually absent in $\operatorname{Tg} 2576$ vessels while the wild type vessels still showed a constriction to ATP followed by a small dilation (Figure 6A). We measured amyloid coverage in three vessels which was $67.9 \pm 4.0 \%$. To test if the vessels from the 12 month old Tg2576 mice can respond to other vasoactive stimuli, we applied alkaline buffer of $\mathrm{pH} 7.65$ and observed a constriction of $10.9 \pm 5.2 \%$, indicating that the arterioles still have some capacity to respond other stimuli.

\section{Extraluminal application of anti- $\mathrm{A} \beta$ antibody $4 \mathrm{G} 8$}

Passive immunization with certain anti $A \beta$ antibodies has shown that such treatment can rapidly improve cognitive function in animal models of $\mathrm{AD}$ [30]. We tested the hypothesis that antibody treatment can interfere with the effect of soluble $A \beta$ on cerebral arterioles. Arterioles were first treated with freshly dissolved $A \beta_{1-40}$, the $A \beta$ washed out, treated with the anti-A $\beta$ antibody $4 \mathrm{G} 8$ antibody (1:200 dilution) and finally the 4G8 washed out. Each treatment applied for 30 minutes and the diameter measured at the end of each treatment. Freshly dissolved $A \beta_{1 \text {. }}$ ${ }_{40}$ significantly constricted the arterioles and this constriction remained even after 30 minutes of washout. Incubation with 4G8 antibody with the vessels, 30 minutes after $A \beta_{1-40}$ washout, restored vessel tone (Figure $6 \mathrm{~B})$. For control experiments we replaced 4G8 antibody with non-specific IgG antibody. In this control experiment non-specific IgG did not restore vessel tone showing that $A \beta_{1-40}$ has a prolonged vasoconstrictive effect even after prolonged washout (Figure 6B). This indicates that $A \beta_{1-40}$ may interact with the vessel even after washout and that antibody to soluble $A \beta$ may interfere with this interaction.

\section{Discussion}

Our study has several notable findings, including the following: 1 ) freshly dissolved $A \beta_{1-40}$ and $A \beta_{1-42}$, but not the reverse peptide $A \beta_{40-1}$, acutely increase vessel tone in rat cerebral penetrating arterioles, with $A \beta_{1-42}$ being equally potent to $A \beta_{1-40}$ except at the highest concentration; 2) $A \beta_{1-40}$ and $A \beta_{1-42}$ both decrease endothelium-dependent dilation to ATP, with $A \beta_{1-42}$ also enhancing smooth muscle dependent constriction; 3) $\mathrm{A} \beta_{1-40}$ decreases arteriolar myogenic response; 4) MnTBAP attenuates $A \beta_{1-40^{-}}$ induced increase in vessel tone increase suggesting that reactive oxygen species have a contributing role in $A \beta$ induced enhancement in vessel tone; 5) $A \beta_{1-40}$ and $A \beta_{1-42}$ acutely increased ROS production in cultured rat cerebral microvascular endothelial and smooth muscle cells in a 


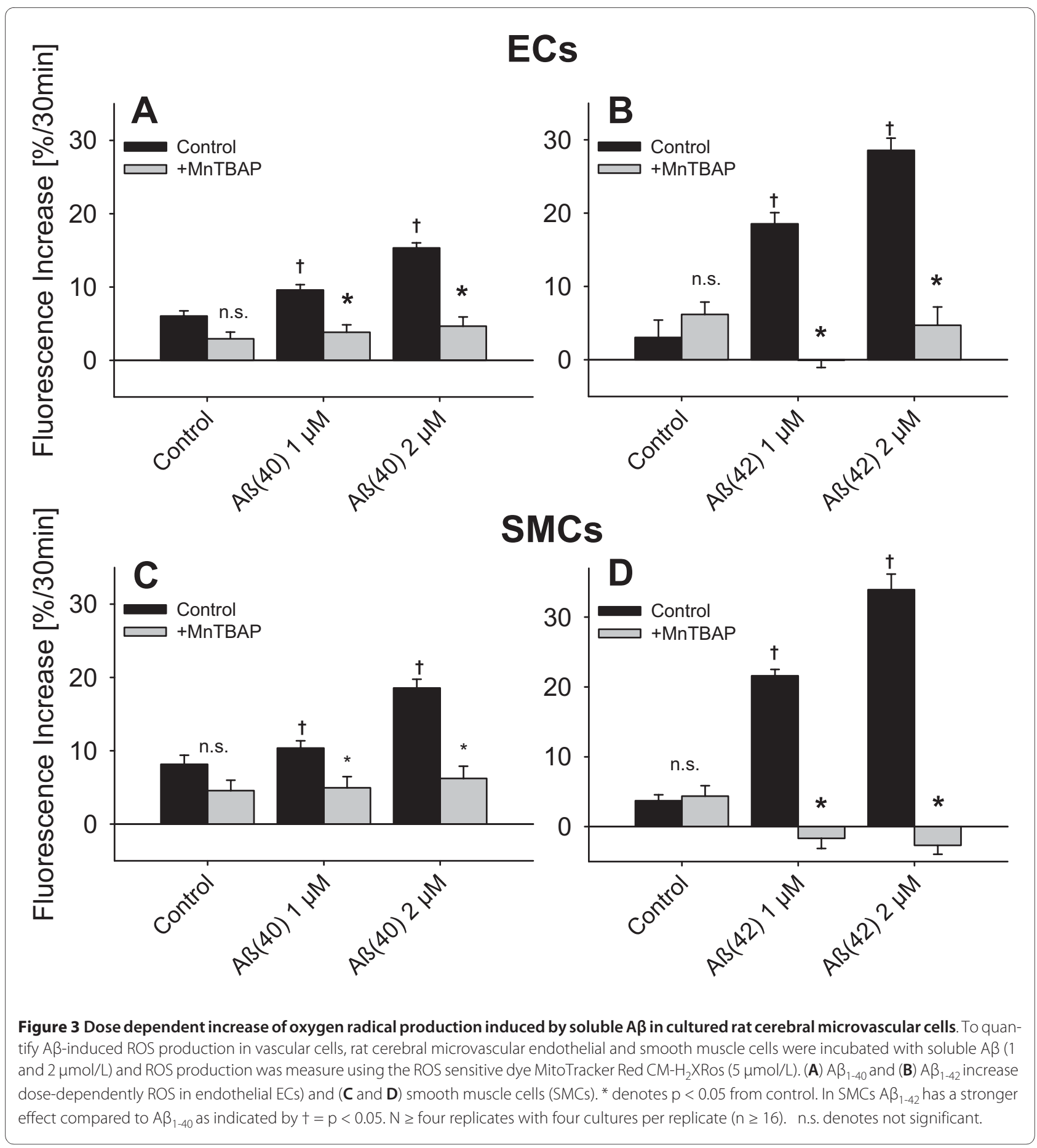

dose dependent fashion - a response that was inhibited by the cell permeable ROS scavenger MnTBAP but not SOD or catalase; 6) Incubation of penetrating arterioles with $A \beta_{1-40}$ for 30 minutes resulted in prolonged increased tone which was not restored by $A \beta$ washout but was restored by the anti-A $\beta$ antibody, 4G8; and 7) exposure to soluble as well as deposited $A \beta$ decreased vascular reactivity over time in arterioles from Tg2576 mice, an animal model of AD. These results confirm many previous reports but also extend our understanding of the vascular effects of soluble $A \beta$, especially in regards to the pathological effects of $A \beta_{1-42}$ on vessels and vascular cells. These results indicate a direct effect of the studied $A \beta$ species on cerebral penetrating arterioles with potentially important differences in their activity such as enhanced arteriolar vasoconstriction to ATP or increased ROS pro- 


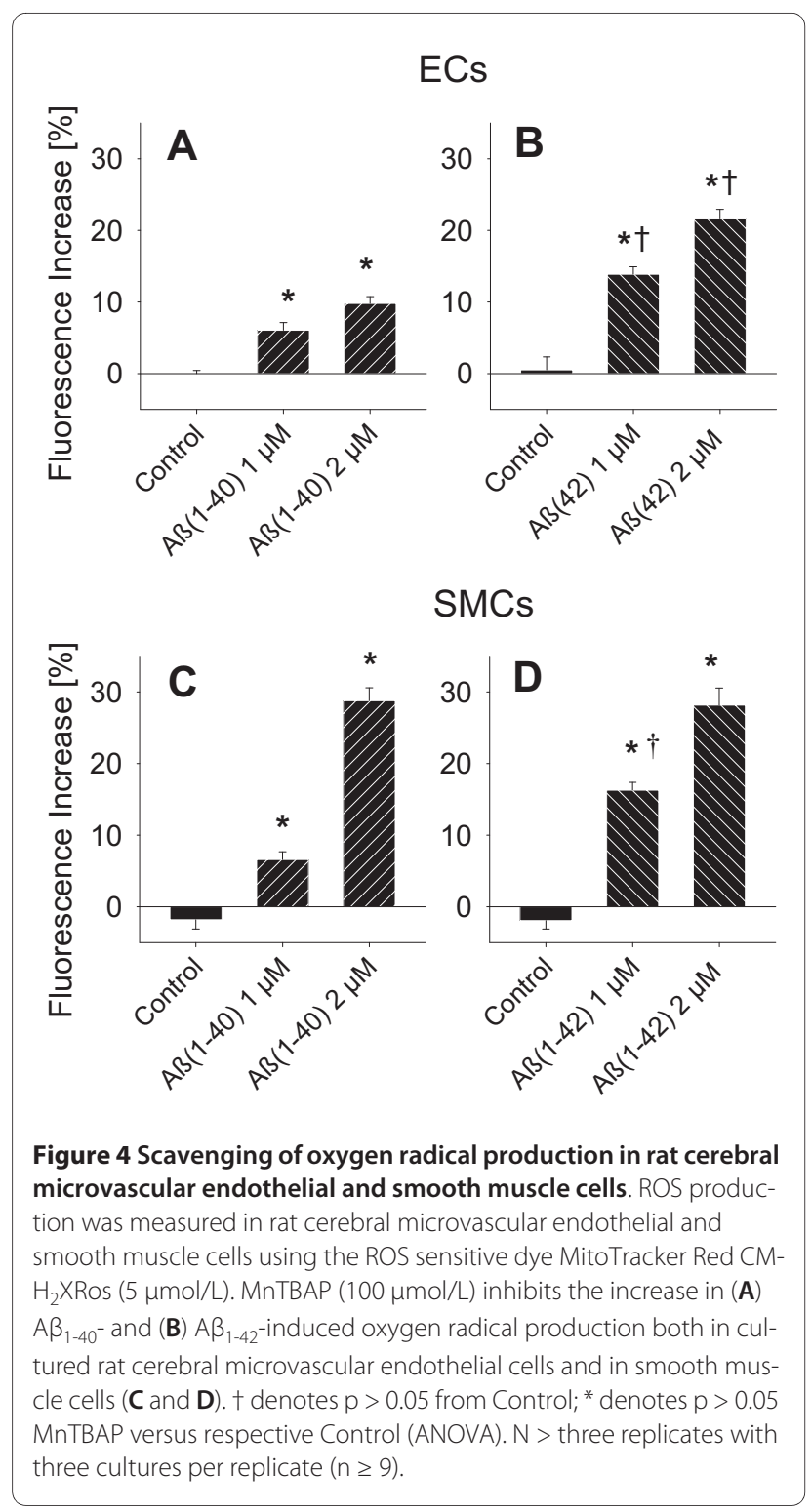

duction by $A \beta_{1-42}$ but increased vessel constriction by $\mathrm{A} \beta_{1-40}$.

The penetrating cerebral arteriole is an important regulator of $\mathrm{CBF}$ representing about $25 \%$ of the total cerebral arterial regulatory capacity. Further, it is the part of the cerebral circulation most profoundly involved in the trafficking of $\mathrm{A} \beta$ from the brain [21] and continuously exposed to $A \beta$. Though the concentration of $A \beta$ in the CSF is in the nanomolar range [31] the concentration in the periarteriolar space is not known and could be higher especially when transport across the arteriole is compromised and $A \beta$ accumulates. Such accumulation would eventually lead to CAA [32]. So far no study has directly addresses the effect of soluble $A \beta$ in this essential microvessel.

\section{Soluble $A \beta$}

In CAA, amyloid deposition consists predominantly of $\mathrm{A} \beta_{1-40}$ rather than $\mathrm{A} \beta_{1-42}$ species [33]; however, in most cases of CAA, $A \beta_{1-42}$ may initially be necessary to induce amyloid deposition [34]. Thus initial studies related to the effect of freshly dissolved $A \beta$ on cerebral vessels that concentrated on $A \beta_{1-40}$ [15]. Niwa et al. directly compared the effects of soluble $A \beta_{1-40}$ versus $A \beta_{1-42}$ in mouse cerebral circulation and found that $A \beta_{1-40}$ but not $A \beta_{1-42}$ recapitulated the observed vascular dysfunction in a mouse model of $A D$ with a high $A \beta_{1-40}$ to $A \beta_{1-42}$ ratio $[5,6,8]$. Similarly, in rat aorta, $A \beta_{1-42}$ was less effective than $A \beta_{1-40}$ [35]. Our data indicate that at concentrations up to 100 $\mathrm{nmol} / \mathrm{L}$ both $\mathrm{A} \beta$ species have a similar effect on rat cerebral arteriolar tone (though at concentrations higher than $100 \mathrm{nmol} / \mathrm{L} \mathrm{A} \beta_{1-40}$ produced greater arteriolar tone). Previous studies found that $A \beta_{1-40}$ reduced endothelium dilation to variety of agonists as well as physiological whisker stimulation $[15,19]$ while $A \beta_{1-42}$ and the reverse peptide $\mathrm{A} \beta_{40-1}$ did not $[5,6,12]$. Adenosine tri-phosphate (ATP) is an important cerebral vasoactive agonist which can be released from numerous sources including cerebral purinergic nerves, astrocytes and red blood cells [36]. Extraluminally applied ATP causes a biphasic diameter response in cerebral arterioles with an initial transient constriction due to smooth muscle cells purinergic $\mathrm{P}_{2 \times 1}{ }^{-}$ receptors [24,36] which quickly desensitize [37] followed by an endothelium-dependent dilation via $\mathrm{P}_{2 \mathrm{Y}}$-receptors $[24,36]$. The effect of A $\beta$ species on ATP-induced vasomotor responses has not been reported previously. We found that similar to other endothelium-dependent agonists, $A \beta_{1-40}$ and $A \beta_{1-42}$ reduce dilation to ATP. Agonistinduced constriction with endothelin or serotonin is increased after $A \beta_{1-40}$ [15]; however, this enhanced constriction was attributed to decreased endothelial function rather than an effect on smooth muscle cells $[5,6,15]$. In mice intraluminal $A \beta_{1-40}$ caused an endothelin-dependent decrease in $\mathrm{CBF}$ which was attenuated by inhibiting the receptor for advanced glycation end products (RAGE) [38]. In our study we found that $A \beta_{1-42}$ but not $A \beta_{1-40}$ enhances constriction to ATP. This constrictive response to ATP is mediated via smooth muscle cells (endothelial denudation does not affect ATP-induced vasoconstriction [36]) and is likely due to desensitization of the $\mathrm{P}_{2 \times 1^{-}}$ receptor responsible for constriction by limiting the time of its activity [36]. The enhanced constriction observed with $A \beta_{1-42}$ likely means that it has a direct effect on smooth muscle cell function either by $A \beta_{1-42}$ prolonging the open probability of the $\mathrm{P}_{2 \mathrm{X} 1}$-receptor or by enhancing the sensitivity of the smooth muscle contractile apparatus. Freshly dissolved $A \beta_{1-40}$ also decreases arteriolar 


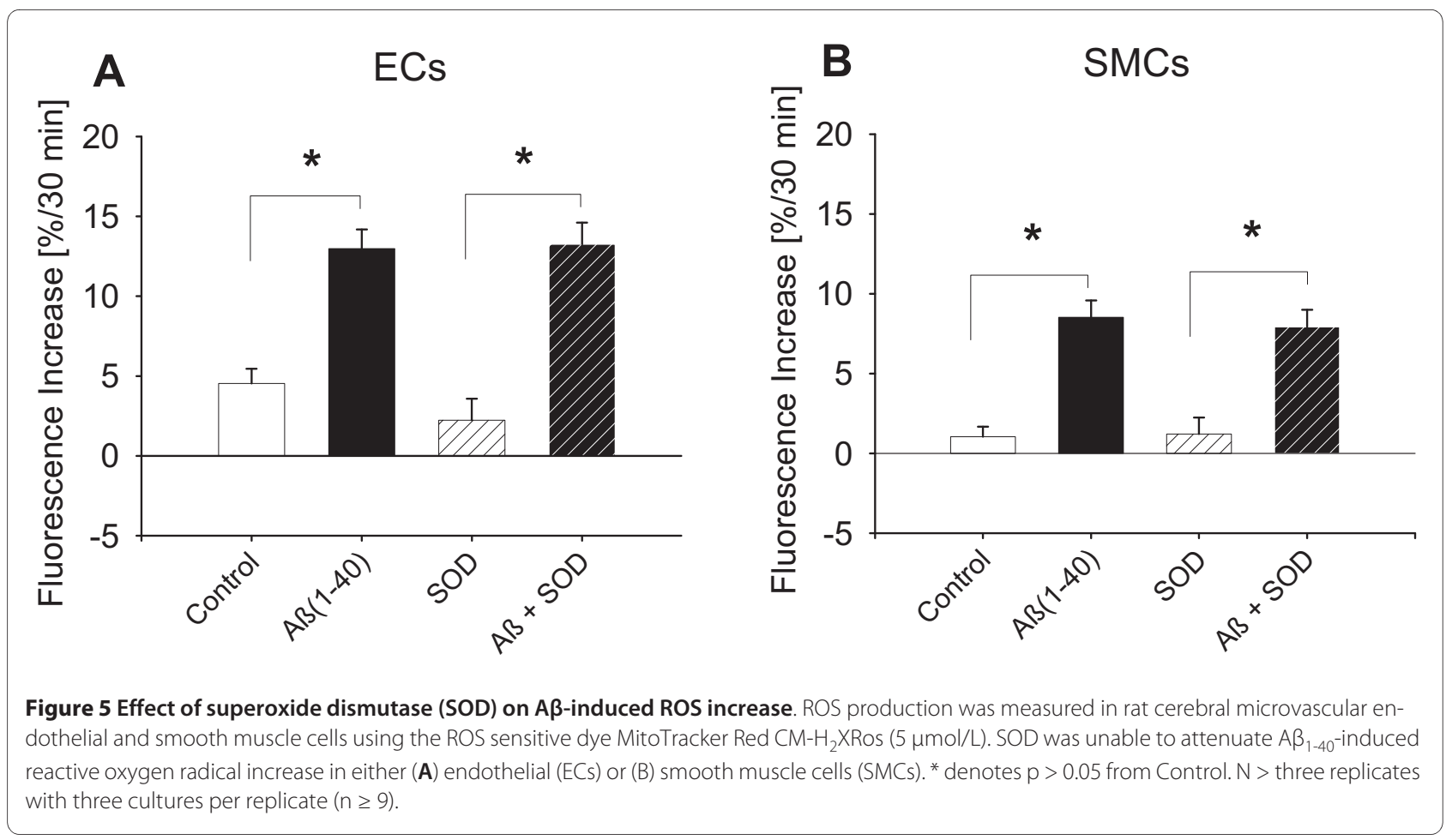

myogenic response. That increased $A \beta$ may decrease myogenic response was shown in a mouse model of $A D$ [6].

Passive immunization with anti-A $\beta$ antibodies is being evaluated as a possible treatment for AD [39]. Dodart et al. showed that passive immunization could rapidly (within 24 to 72 hours) improve cognitive function in an animal model of AD [30]. We therefore hypothesized that an antibody against $A \beta$ may rapidly ameliorate $A \beta$ induced increase in arteriolar tone. We found that a 30 minute incubation with $A \beta_{1-40}$ resulted in a persistent (> 90 minutes) increase in arteriolar tone despite repeated washouts. This indicates that, once in contact with the vessel, $A \beta_{1-40}$ retains its vasoactive effect even in the absence of extravascular $A \beta$ for some time. However, after application of the anti-A $\beta$ antibody 4G8, the arteriolar tone was restored while non-specific IgG had no effect. This observation is consistent with the notion that $\mathrm{A} \beta_{1-40}$ resides on the cell surface in such a way that only high affinity binding agents can remove or neutralize. Alternatively the $A \beta$ signaling mechanism may be slow to come on and slow to turn off. Further studies are needed to resolve the mechanism of soluble $\mathrm{A} \beta$-induced arteriolar dysfunction. Taken together we present for the first time evidence that soluble $A \beta_{1-40}$ as well as $A \beta_{1-42}$ directly impair cerebral penetrating arteriolar function and that $\mathrm{A} \beta_{1-42}$ may be considered a vasoactive $A \beta$ species in this preparation.

\section{ROS}

The mechanism behind cerebral vascular dysfunction due to soluble $A \beta$ is not completely understood. There is evidence that ROS are involved [15,17-19]. Since peroxynitrite did not duplicate soluble $A \beta$-induced vascular dysfunction in rat aorta [17], superoxide anion produced by NADPH oxidase may contribute to the observed vascular dysfunction $[17,18]$. Other studies suggest that soluble $\mathrm{A} \beta$ causes activation of $\mathrm{COX}-2$ and other inflammatory responses resulting in the observed vascular dysfunction $[13,40]$. Soluble $A \beta$ may trigger intracellular calcium mobilization which may activate calcium sensitive PKCs resulting in deactivation of eNOS [16].

We applied the cell permeant oxygen radical scavenger MnTBAP to cerebral arterioles ex vivo and found a partial restoration of arteriolar tone, indicating that oxygen radicals contribute to the increased tone development by $\mathrm{A} \beta$. To further elucidate the acute effect of freshly dissolved $A \beta$ on vascular cells, we measured ROS production in rat cerebro-microvascular endothelial and smooth muscle cells. Our results show, that freshly dissolved $A \beta_{1-40}$ and $A \beta_{1-42}$ dose-dependently increase ROS production in both endothelial and smooth muscle cells with $\mathrm{A} \beta_{1-42}$ having a greater ability to induce oxygen radical formation. This indicates that both $A \beta$ species may acutely interfere with either cell type and their function in vascular regulation. Studies show that extraluminal $\mathrm{A} \beta_{1-40}$ damages cerebrovascular endothelium and impairs function within 30 minutes of incubation $[15,40]$ indicating 


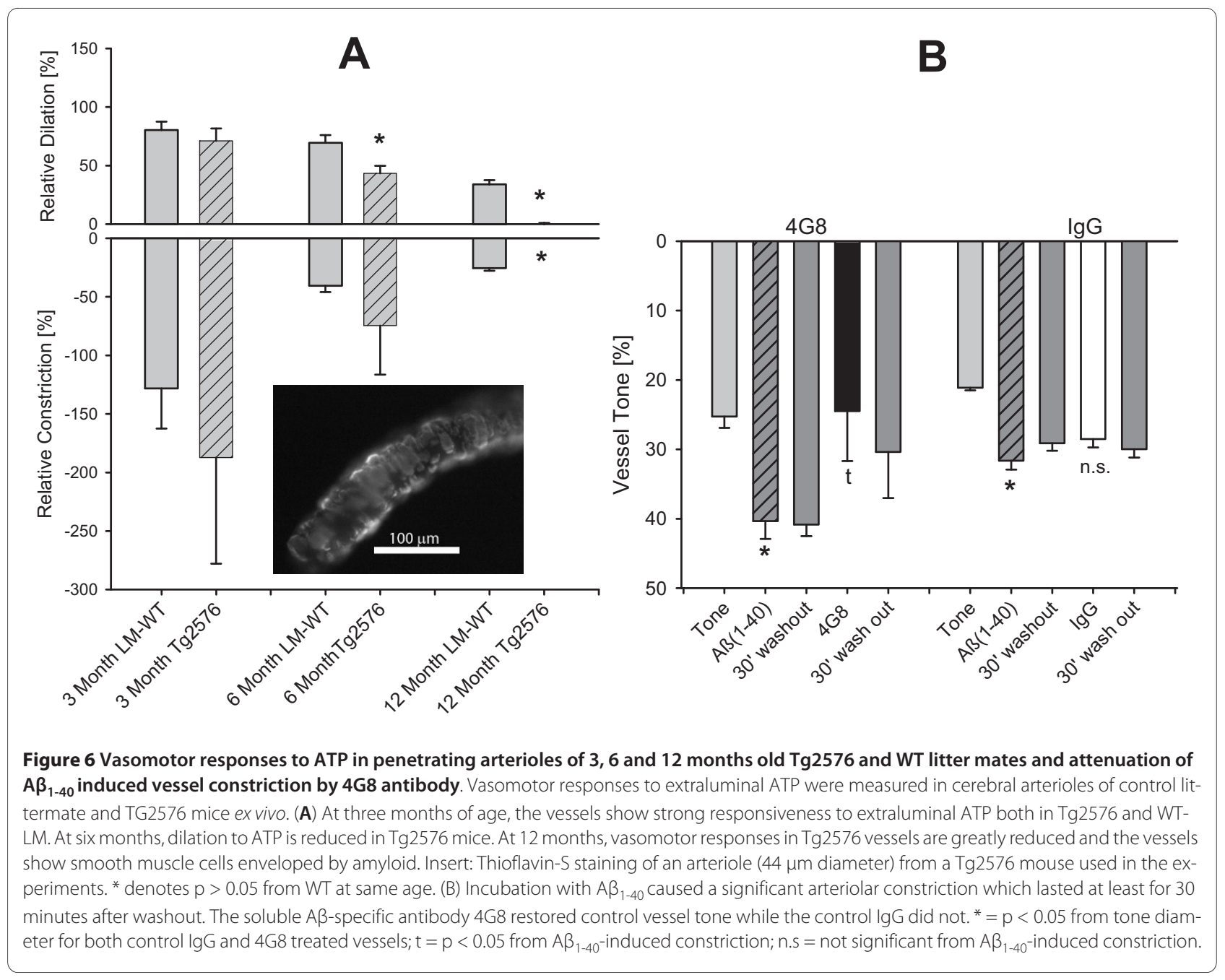

that $A \beta$ quickly reacts with vascular cells. This suggests that $A \beta$ may reach the abluminal endothelium to exert a direct endothelial effect similar to other small peptides such as bradykinin. While we and others found that $A \beta$ directly affects endothelial cells in culture, experiments with extraluminal $A \beta$ application are not consistent as to whether extraluminal $A \beta$ directly affects the endothelium or if the $A \beta$ effect is limited to the vascular smooth muscle from which a noxious mediator may diffuse to the endothelium. Catalase and superoxide dismutase (SOD) did not affect the $A \beta$-induced ROS production. MnTBAP is a cell permeable SOD-mimetic, as such MnTBAP scavenges $\mathrm{O}_{2}{ }^{-}$at the source, presumably the mitochondria. SOD is not cell permeant and $\mathrm{O}_{2}$ - does not diffuse well out of the cell due to its polarity. As such SOD is expected to have less or no effect of scavenging intracellular ROS. Catalase metabolizes $\mathrm{H}_{2} \mathrm{O}_{2}$ to $\mathrm{H}_{2} \mathrm{O}$ and $\mathrm{O}_{2}-\mathrm{H}_{2} \mathrm{O}_{2}$ is cell permeant and could be metabolized by extracellular catalase. However, since catalase did not change the ROS signal, $\mathrm{H}_{2} \mathrm{O}_{2}$ may not be involved in the observed $\mathrm{ROS}$ production. No study on the acute effect of $A \beta$-induced ROS on cerebral microvascular endothelial cells in vitro exists though cytotoxicity following a 24 hour exposure of cells incubated with $A \beta_{1-40}$, was reduced by MnTBAP in RBE4 cells indicating that ROS were produced [17]. A consequence of oxidative stress is increased lipid peroxidation, measured e.g. as thiobarbituric acid reactive substances (TBARS), which was increased in cultured astrocytes after 24 hour incubation with $\mathrm{A} \beta_{1-40}$ [41]. While we were able to detect an increase in ROS with MitoTracker Red CM- $\mathrm{H}_{2}$ XRos fluorescence, in preliminary experiments we could not detect an increase in lipid peroxidation with thirty minutes of $A \beta$ incubation. It is likely that this incubation time is not long enough to result in a lipid peroxidation detectable by the TBARS method and more sensitive approaches such a mass spectroscopy have to be used.

Though no observations for acute effects exist, differences in the effect of $A \beta$ species on endothelial cells were found in several studies. Folin et al. found that $A \beta_{1-40}$ was 
less toxic to neuro-endothelial cells than $A \beta_{1-42}$ [42] while the opposite was found for human cerebrovascular endothelial cells [43]. In other vascular endothelial cells it was found that $A \beta_{1-40}$ reduces production of nitric oxide $[16,20]$. The effect of the vasculotropic Dutch (E693Q)/ Iowa (D694N) mutant human $A \beta_{1-40} \mathrm{D}$ was studied in human cerebro-vascular smooth muscle cells. The study found that $\mathrm{A} \beta_{1-40} \mathrm{D}$ did not increase ROS production [44]. Other mechanisms such as increased intracellular calcium activity [16] or decreased endothelial nitric oxide availability [20] have been reported which could also contribute to the observed vascular dysfunction.

\section{Chronic exposure to soluble $A \beta$}

To test if chronic exposure to increased $A \beta$ levels affects arteriolar vasomotor function over time, we compared arteriolar diameter responses of vessels from $\mathrm{Tg} 2576$ mice, a commonly used AD mouse model having elevated levels of soluble $A \beta$ throughout life and age-dependent development of CAA [28], with age matched littermate controls. We found no difference in vessel responses to ATP at three months of age, but at six months of age, dilation to ATP was reduced in Tg2576 mice. There was also a trend towards increased tone and increased ATPinduced vasoconstriction, but this did not reach statistical significance. In 12 month old $\operatorname{Tg} 2576$ mice, the vasomotor response to ATP was essentially absent. Stimulation with alkaline $\mathrm{pH}$ still resulted in some constriction indicating that the vessels were responsive to some physiological stimulus. At this age, the vessels evaluated had CAA coverage of approximately $67 \%$. Amyloid can also be sequestered in the basement membrane $[45,46]$ which may be more likely to occur with basement membrane thickening that occurs with age. This will affect vessel functionality. Further accumulation of soluble $A \beta$ could lead to formation of $A \beta$ oligomers which in some studies are shown to be more effective/toxic than monomeric soluble $A \beta$ [47]. The possible effect of $A \beta$ oligomers on cerebral arterioles will be important to assess in future experiments. The lack of vasodilation in these vessels corresponds well with in vivo observations in pial arterioles where a CAA coverage of $50 \%$ or more eliminated dilatory response to hypercapnia [8]. The same study also found that in 12 month old TG2576 vessels, the smooth muscle content was significantly reduced. Thus increased CAA coverage and decreased smooth muscle content could, in part, explain the weak constrictory response observed at this age in our ex vivo studies.

Taken together these findings indicate that on the arteriolar level, chronic exposure to $\mathrm{A} \beta$ may lead to alterations in vasomotor function as early as six months of age when no amyloid deposits are present $[5,8]$. Though vessel function decreases with age, it deteriorates severely in
Tg2576 animals. Relative CBF was found to be decreased in 13 month old $\mathrm{Tg} 2576$ mice [7]. CBF responses to a variety of stimuli in Tg2576 mice of 8 months (pre-CAA) was not different from age matched controls though they were depressed in 19 month old animals $[9,10]$. While our and the above studies did not observe vascular anomalies in $\operatorname{Tg} 2576$ mice younger than 6 months of age, Niwa et al. found decreased CBF responses in young (two to three months) Tg2576 mice [6]. It should be noted, however, that our data at 3 months of age did show a trend for decreased dilation and increased vasoconstriction in $\operatorname{Tg} 2576$ mice indicating that increased $A \beta$ may have begun to effect cerebral arteriole function early in life.

\section{Conclusions}

Utilizing isolated rat cerebral arterioles ex vivo, we found that both $A \beta_{1-40}$ and $A \beta_{1-42}$ cause vessel constriction and reduced dilation to ATP, with $A \beta_{1-42}$ also enhancing arteriolar constriction response. Together with the observed loss of myogenic response, increased soluble $A \beta$ levels may lead to pronounced vessel dysfunction in vivo. Both $\mathrm{A} \beta_{1-40}$ and $\mathrm{A} \beta_{1-42}$ increased oxygen radical production in cerebro-microvascular endothelial and smooth muscle cells which was inhibited by MnTBAP, indicating that oxygen radicals, in part, contribute to $A \beta$-induced penetrating arteriole dysfunction. The effects of $A \beta$-incubation on cerebral arterioles persists after washout but can be alleviated with an anti-A $\beta$ antibody, suggesting that $A \beta$ may exert its effects while bound to the cell surface. Chronic exposure to elevated $A \beta$ results in cerebral microvascular dysfunction before CAA at six months of age which worsened with age resulting in minimal responsiveness at 12 months with CAA present. Overall the results suggest that soluble and fibrillar $A \beta$ is influencing arteriolar function which may have an important effect on brain dysfunction in AD and CAA and may contribute to ischemia.

\section{Competing interests}

The authors declare that they have no competing interests.

\section{Authors' contributions}

HHD contributed to the general design of the ex vivo and in vitro experiments, performed ex vivo experiments and supervised the in vitro studies, and contributed to the statistical data analysis and the writing of the manuscript. CX performed additional ex vivo experiments and contributed to the statistical analysis. BHH performed the CAA coverage analysis. GJZ contributed to the design, analysis and interpretation of the studies, writing and review of the manuscript. DMH contributed to the overall experimental design, data interpretation and critical manuscript review. All authors have read and approved the final manuscript.

\section{Acknowledgements}

This work was supported by National Institutes of Health $(\mathrm{NIH})$ grants NS032636 (HHD, GJZ and DMH), AG13956 (DMH), NS053899 (GJZ), NS30555 (HHD) and HL41250 (HHD) and American Health Assistance Foundation (GJZ) 


\section{Author Details}

'Department of Neurological Surgery, Hope Center for Neurological Disorders, and Alzheimer's Disease Research Center, Washington University School of Medicine, St Louis, MO, 63110, USA, 2Department of Neurological Surgery, Washington University School of Medicine, St Louis, MO, 63110, USA, ${ }^{3}$ Departments of Neurological Surgery, Neurology, and Hope Center for Neurological Disorders, Washington University School of Medicine, St Louis, MO, 63110, USA and 4Department of Neurology, Hope Center for Neurological Disorders, and Alzheimer's Disease Research Center, Washington University School of Medicine, St Louis, MO, 63110, USA

Received: 7 January 2010 Accepted: 13 April 2010

Published: 13 April 2010

\section{References}

1. Selkoe DJ: Alzheimer's disease: genes, proteins, and therapy. Physio/ Rev 2001, 81:741-766.

2. Steiner $\mathrm{H}$, Haass $\mathrm{C}$ : Intramembrane proteolysis by presenilins. Nat Rev Mol Cell Biol 2000, 1:217-224

3. Ruitenberg A, den HT, Bakker SL, van Swieten JC, Koudstaal PJ, Hofman A, Breteler MM: Cerebral hypoperfusion and clinical onset of dementia: the Rotterdam Study. Ann Neurol 2005, 57:789-794.

4. Zhang F, Eckman C, Younkin S, Hsiao KK, ladecola C: Increased susceptibility to ischemic brain damage in transgenic mice overexpressing the amyloid precursor protein. J Neurosci 1997, 17:7655-7661.

5. Niwa K, Younkin L, Ebeling C, Turner SK, Westaway D, Younkin S, Ashe KH, Carlson GA, ladecola C: Abeta 1-40-related reduction in functional hyperemia in mouse neocortex during somatosensory activation. Proc Natl Acad Sci USA 2000, 97:9735-9740.

6. Niwa K, Kazama K, Younkin L, Younkin SG, Carlson GA, ladecola C: Cerebrovascular autoregulation is profoundly impaired in mice overexpressing amyloid precursor protein. Am J Physiol Heart Circ Physiol 2002, 283:H315-H323.

7. Paris D, Quadros A, Humphrey J, Patel N, Crescentini R, Crawford F, Mullan M: Nilvadipine antagonizes both Abeta vasoactivity in isolated arteries, and the reduced cerebral blood flow in APPsw transgenic mice. Brain Res 2004, 999:53-61.

8. Han BH, Zhou ML, Abousaleh F, Brendza RP, Dietrich HH, KoenigsknechtTalboo J, Cirrito JR, Milner E, Holtzman DM, Zipfel GJ: Cerebrovascular dysfunction in amyloid precursor protein transgenic mice: contribution of soluble and insoluble amyloid-beta peptide, partial restoration via gamma-secretase inhibition. J Neurosci 2008, 28:13542-13550.

9. Shin HK, Jones PB, Garcia-Alloza M, Borrelli L, Greenberg SM, Bacskai BJ, Frosch MP, Hyman BT, Moskowitz MA, Ayata C: Age-dependent cerebrovascular dysfunction in a transgenic mouse model of cerebral amyloid angiopathy. Brain 2007, 130:2310-2319.

10. Christie R, Yamada M, Moskowitz M, Hyman B: Structural and functional disruption of vascular smooth muscle cells in a transgenic mouse model of amyloid angiopathy. Am J Pathol 2001, 158:1065-1071.

11. Suo Z, Humphrey J, Kundtz A, Sethi F, Placzek A, Crawford F, Mullan M: Soluble Alzheimers beta-amyloid constricts the cerebral vasculature in vivo. Neurosci Lett 1998, 257:77-80.

12. Niwa K, Porter VA, Kazama K, Cornfield D, Carlson GA, ladecola C: A peptides enhance vasoconstriction in cerebral circulation. Am J Physiol Heart Circ Physiol 2001, 281:H2417-H2424.

13. Paris D, Humphrey J, Quadros A, Patel N, Crescentini R, Crawford F, Mullan $M$ : Vasoactive effects of $A$ beta in isolated human cerebrovessels and in a transgenic mouse model of Alzheimer's disease: role of inflammation. Neurol Res 2003, 25:642-651.

14. Thomas T, McLendon C, Sutton ET, Thomas G: Cerebrovascular endothelial dysfunction mediated by beta-amyloid. Neuroreport 1997 8:1387-1391.

15. Price JM, Sutton ET, Hellermann A, Thomas T: beta-Amyloid induces cerebrovascular endothelial dysfunction in the rat brain. Neurol Res 1997, 19:534-538.

16. Gentile MT, Vecchione C, Maffei A, Aretini A, Marino G, Poulet R, Capobianco L, Selvetella G, Lembo G: Mechanisms of soluble betaamyloid impairment of endothelial function. J Biol Chem 2004, 279:48135-48142
17. Paris D, Parker TA, Town T, Suo Z, Fang C, Humphrey J, Crawford F, Mullan M: Role of peroxynitrite in the vasoactive and cytotoxic effects of Alzheimer's beta-amyloid1-40 peptide. Exp Neurol 1998, 152:1 16-122.

18. Park L, Anrather J, Zhou P, Frys K, Pitstick R, Younkin S, Carlson GA, ladecola C: NADPH-oxidase-derived reactive oxygen species mediate the cerebrovascular dysfunction induced by the amyloid beta peptide. $J$ Neurosci 2005, 25:1769-1777.

19. Niwa K, Carlson GA, ladecola C: Exogenous A beta1-40 reproduces cerebrovascular alterations resulting from amyloid precursor protein overexpression in mice. J Cereb Blood Flow Metab 2000, 20:1659-1668.

20. Price JM, Chi X, Hellermann G, Sutton ET: Physiological levels of betaamyloid induce cerebral vessel dysfunction and reduce endothelial nitric oxide production. Neurol Res 2001, 23:506-512.

21. Deane R, Wu Z, Zlokovic BV: RAGE (yin) versus LRP (yang) balance regulates alzheimer amyloid beta-peptide clearance through transport across the blood-brain barrier. Stroke 2004, 35:2628-2631.

22. Dacey RG Jr, Duling BR: A study of rat intracerebral arterioles: methods, morphology, and reactivity. Am J Physiol 1982, 243:H598-H606.

23. You JP, Johnson TD, Marrelli SP, Bryan RM Jr: Functional heterogeneity of endothelial P2 purinoceptors in the cerebrovascular tree of the rat. Am J Physiol Heart Circ Physiol 1999, 277:H893-H900.

24. Dietrich HH, Horiuchi T, Xiang C, Hongo K, Falck JR, Dacey RG Jr: Mechanism of ATP-induced local and conducted vasomotor responses in isolated rat cerebral penetrating arterioles. J Vasc Res 2009, 46:253-264

25. Diglio CA, Grammas P, Giacomelli F, Wiener J: Rat cerebral microvascular smooth muscle cells in culture. J Cell Physiol 1986, 129:131-141.

26. Diglio CA, Wolfe DE, Meyers P: Transformation of rat cerebral endothelial cells by rous sarcoma virus. J Cell Biol 1983, 97:15-21.

27. You JP, Johnson TD, Marrelli SP, Mombouli JV, Bryan RM Jr: $\mathrm{P}_{2 u}$ receptormediated release of endothelium-derived relaxing factor nitric oxide and endothelium-derived hyperpolarizing factor from cerebrovascular endothelium in rats. Stroke 1999, 30:1125-1132.

28. Hsiao K, Chapman P, Nilsen S, Eckman C, Harigaya Y, Younkin S, Yang F, Cole G: Correlative memory deficits, Abeta elevation, and amyloid plaques in transgenic mice. Science 1996, 274:99-102.

29. Fryer JD, Taylor JW, DeMattos RB, Bales KR, Paul SM, Parsadanian M, Holtzman DM: Apolipoprotein E markedly facilitates age-dependent cerebral amyloid angiopathy and spontaneous hemorrhage in amyloid precursor protein transgenic mice. J Neurosci 2003, 23:7889-7896.

30. Dodart JC, Bales KR, Gannon KS, Greene SJ, DeMattos RB, Mathis C, DeLong CA, Wu S, Wu X, Holtzman DM, et al: Immunization reverses memory deficits without reducing brain Abeta burden in Alzheimer's disease model. Nat Neurosci 2002, 5:452-457.

31. Oh ES, Troncoso JC, Fangmark Tucker SM: Maximizing the potential of plasma amyloid-beta as a diagnostic biomarker for Alzheimer's disease. Neuromolecular Med 2008, 10:195-207.

32. Bell RD, Deane R, Chow N, Long X, Sagare A, Singh I, Streb JW, Guo H, Rubio A, Nostrand W, et al.: SRF and myocardin regulate LRP-mediated amyloid-beta clearance in brain vascular cells. Nat Cell Biol 2008.

33. Gravina SA, Ho L, Eckman CB, Long KE, Otvos L Jr, Younkin LH, Suzuki N, Younkin SG: Amyloid beta protein (A beta) in Alzheimer's disease brain. Biochemical and immunocytochemical analysis with antibodies specific for forms ending at A beta 40 or A beta 42(43). J Biol Chem 1995, 270:7013-7016.

34. McGowan E, Pickford F, Kim J, Onstead L, Eriksen J, Yu C, Skipper L, Murphy MP, Beard J, Das P, et al: Abeta42 is essential for parenchymal and vascular amyloid deposition in mice. Neuron 2005, 47:191-199.

35. Suo Z, Fang C, Crawford F, Mullan M: Superoxide free radical and intracellular calcium mediate A beta(1-42) induced endothelial toxicity. Brain Res 1997, 762:144-152.

36. Horiuchi T, Dietrich HH, Tsugane S, Dacey RG Jr: Analysis of purine- and pyrimidine-induced vascular responses in the isolated rat cerebral arteriole. American Journal of Physiology - Heart \& Circulatory Physiology 2001, 280:H767-H776.

37. Gever JR, Cockayne DA, Dillon MP, Burnstock G, Ford AP: Pharmacology of P2X channels. Pflugers Arch 2006, 452:513-537.

38. Deane R, Du YS, Submamaryan RK, LaRue B, Jovanovic S, Hogg E, Welch D, Manness L, Lin C, Yu J, et al:: RAGE mediates amyloid-beta peptide transport across the blood-brain barrier and accumulation in brain. Nat Med 2003, 9:907-913. 
39. Brody DL, Holtzman DM: Active and passive immunotherapy for neurodegenerative disorders. Annu Rev Neurosci 2008, 31:175-193.

40. Rhodin J, Thomas T, Bryant M, Sutton ET: Animal model of Alzheimer-like vascular pathology and inflammatory reaction. Ann N Y Acad Sci 2000, 903:345-352.

41. Matos M, Augusto E, Oliveira CR, Agostinho P: Amyloid-beta peptide decreases glutamate uptake in cultured astrocytes: involvement of oxidative stress and mitogen-activated protein kinase cascades. Neuroscience 2008, 156:898-910.

42. Folin M, Baiguera S, Tommasini M, Guidolin D, Conconi MT, De CE, Nussdorfer GG, Parnigotto PP: Effects of beta-amyloid on rat neuromicrovascular endothelial cells cultured in vitro. Int J Mol Med 2005, 15:929-935.

43. Eisenhauer PB, Johnson RJ, Wells JM, Davies TA, Fine RE: Toxicity of various amyloid beta peptide species in cultured human blood-brain barrier endothelial cells: increased toxicity of dutch-type mutant. $J$ Neurosci Res 2000, 60:804-810

44. Jung SS, Van Nostrand WE: Abeta does not induce oxidative stress in human cerebrovascular smooth muscle cells. Neuroreport 2002, 13:1309-1312

45. Maat-Schieman M, Roos R, van Duinen S: Hereditary cerebral hemorrhage with amyloidosis-Dutch type. Neuropathology 2005, 25:288-297.

46. Herzig MC, Winkler DT, Burgermeister P, Pfeifer M, Kohler E, Schmidt SD, Danner S, Abramowski D, Sturchler-Pierrat C, Burki K, et al:: Abeta is targeted to the vasculature in a mouse model of hereditary cerebral hemorrhage with amyloidosis. Nat Neurosci 2004, 7:954-960

47. Glabe CG: Structural classification of toxic amyloid oligomers. J Biol Chem 2008, 283:29639-29643.

doi: 10.1186/1750-1326-5-15

Cite this article as: Dietrich et al., Soluble amyloid-?, effect on cerebral arteriolar regulation and vascular cells Molecular Neurodegeneration 2010, 5:15

Submit your next manuscript to BioMed Central and take full advantage of:

- Convenient online submission

- Thorough peer review

- No space constraints or color figure charges

- Immediate publication on acceptance

- Inclusion in PubMed, CAS, Scopus and Google Scholar

- Research which is freely available for redistribution

Submit your manuscript at www.biomedcentral.com/submit
Ciomed Central 